\title{
Regulation of Serum Sodium Levels during Chemotherapy Using Selective Arginine Vasopressin V2-Receptor Antagonist Tolvaptan in a Four-Year-Old Girl with a Suprasellar Germ Cell Tumor
}

\author{
Shota Hiroshima ${ }^{1}$, Hiromi Nyuzuki ${ }^{1}$, Sunao Sasaki ${ }^{1}$, Yohei Ogawa ${ }^{1,2}$ and Keisuke Nagasaki ${ }^{1, * \mathbb{D}}$ \\ 1 Division of Pediatrics, Department of Homeostatic Regulation and Development, Niigata University \\ Graduate School of Medical and Dental Sciences, Niigata 951-8510, Japan; sho980522@gmail.com (S.H.); \\ nyuzuki@med.niigata-u.ac.jp (H.N.); sunaoenari@gmail.com (S.S.); yohei_oga@yahoo.co.jp (Y.O.) \\ 2 Division of Community Medicine, Department of Community Medicine, Niigata University Graduate School \\ of Medical and Dental Sciences, Niigata 951-8510, Japan \\ * Correspondence: nagasaki@med.niigata-u.ac.jp; Tel.: +81-025-227-2222
}

\section{check for} updates

Citation: Hiroshima, S.; Nyuzuki, H.; Sasaki, S.; Ogawa, Y.; Nagasaki, K. Regulation of Serum Sodium Levels during Chemotherapy Using

Selective Arginine Vasopressin

V2-Receptor Antagonist Tolvaptan in a Four-Year-Old Girl with a Suprasellar Germ Cell Tumor. Children 2021, 8, 293. https:// doi.org/10.3390/children8040293

Academic Editor: Pierluigi Marzuillo

Received: 10 March 2021

Accepted: 8 April 2021

Published: 10 April 2021

Publisher's Note: MDPI stays neutral with regard to jurisdictional claims in published maps and institutional affiliations.

Copyright: (c) 2021 by the authors. Licensee MDPI, Basel, Switzerland. This article is an open access article distributed under the terms and conditions of the Creative Commons Attribution (CC BY) license (https:// creativecommons.org/licenses/by/ $4.0 /)$.

\begin{abstract}
There are limited reports on the use of tolvaptan for syndrome of inappropriate antidiuretic hormone secretion (SIADH) in children. Managing serum sodium levels in SIADH patients during chemotherapy is often difficult because of the need for massive fluid infusions. We report the course of the use of tolvaptan for the treatment of hyponatremia during chemotherapy in a four-yearold girl with a suprasellar germ cell tumor. The patient was a Japanese girl who presented with left ptosis with a mass in the pituitary gland and cavernous sinus. She was diagnosed with an intermediate-grade germ cell tumor and was treated with carboplatin and etoposide combination chemotherapy. She developed hyponatremia due to SIADH caused by intravenous infusion therapy before chemotherapy. Subsequently, tolvaptan $(3.25 \mathrm{mg} ; 0.20 \mathrm{mg} / \mathrm{kg} /$ dose $)$ was administered orally to control serum sodium levels. After $4 \mathrm{~h}$ of administration, a marked increase in urine volume of up to $15 \mathrm{~mL} / \mathrm{kg} / \mathrm{h}$ was observed, and serum sodium level increased from 126 to $138 \mathrm{mEq} / \mathrm{L}$ after $10 \mathrm{~h}$ of tolvaptan administration, followed by a decrease in urine volume. The use of tolvaptan in pediatric patients with SIADH who require intravenous hydration during chemotherapy can be useful for the management of serum sodium balance.
\end{abstract}

Keywords: tolvaptan; hyponatremia; pediatric SIADH; germ cell tumor; chemotherapy

\section{Introduction}

Syndrome of inappropriate antidiuretic hormone secretion (SIADH) is a condition in which, despite low osmotic pressure, arginine vasopressin (AVP) secretion is not suppressed, AVP is continuously secreted, and excess body fluid accumulates because of the promotion of water reabsorption within the renal collecting tubule, resulting in diluted hyponatremia [1,2]. SIADH can be caused by central nervous system diseases, lung diseases, ectopic vasopressin production, and drugs [3]. The first line of SIADH treatment is to eliminate the underlying cause when possible, and the second line is the restriction of water [3], in addition to hypertonic fluids, loop diuretics, and oral urea [4]. However, managing serum sodium levels in SIADH patients during chemotherapy is often difficult because of the need for massive fluid infusions.

The vasopressin type- 2 receptor antagonist tolvaptan can be used to treat hyponatremia. Tolvaptan selectively and competitively binds to and blocks the V2 receptor located in the walls of the vasculature and luminal membranes of renal collecting ducts, thereby preventing the binding of vasopressin to the V2 receptor [1,2]. This prevents water absorption in the renal collecting tubule and increases the excretion of electrolyte-free water via the kidneys [1,2]. This reduces the intravascular volume and increases serum sodium 
concentration and osmolality. Mozavaptan hydrochloride was previously approved in Japan as a vasopressin type-2 receptor antagonist for the treatment of SIADH in ectopic vasopressin-producing tumors in 2006. In June 2020, tolvaptan was approved in Japan for the treatment of SIADH in adults [5]. Tolvaptan was approved in 2009 in the United States and European countries for the treatment of hyponatremia, but there have been limited reports of its use for SIADH in children.

Herein, we report the course of the use of tolvaptan for the treatment of hyponatremia during chemotherapy in a four-year-old girl with a suprasellar germ cell tumor presenting with SIADH.

\section{Case Presentation}

The patient was the first child of Japanese non-consanguineous parents. She was born at full-term via normal delivery, and her birth weight was $3482 \mathrm{~g}$. Neonatal screening tests were within the normal range. She was a healthy girl until four years of age. She visited our department presenting with left ptosis, left eye abduction failure, and left low vision. Contrast-enhanced T1-weighted imaging revealed a mass with inhomogeneous enhancement in the pituitary region, cavernous sinus, and enlargement of the pituitary stalk. Based on the biopsy results, she was diagnosed with an intermediate-grade germ cell tumor and was treated with carboplatin and etoposide combination chemotherapy (CARE therapy). Serum Na levels at admission and after biopsy were 137 and $132 \mathrm{mEq} / \mathrm{L}$, respectively, ranging from normal to mildly low. Following hydration therapy before chemotherapy, she presented with neck pain and a decrease in serum sodium levels due to SIADH (Table 1). Her cardiac and renal functions were normal, and there were no findings of dehydration. In addition, the insulin, thyrotropin-releasing hormone, and luteinizing hormone-releasing hormone test results showed normal hypothalamic-pituitary-adrenal function.

Table 1. Laboratory data in hyponatremia before the chemotherapy.

\begin{tabular}{|c|c|c|c|c|c|c|}
\hline Blood Chemistry & & & $\begin{array}{c}\text { Endocrine } \\
\text { Tests }\end{array}$ & & & $\begin{array}{c}\text { (Reference } \\
\text { Values) }\end{array}$ \\
\hline $\mathrm{TP}$ & 6.5 & $\mathrm{~g} / \mathrm{dL}$ & $\mathrm{ADH}$ & 1.1 & $\mathrm{pg} / \mathrm{mL}$ & $<0.5$ \\
\hline BUN & 8.0 & $\mathrm{mg} / \mathrm{dL}$ & BNP & $<5.8$ & $\mathrm{pg} / \mathrm{mL}$ & $<18.4$ \\
\hline UA & 3.9 & $\mathrm{mg} / \mathrm{dL}$ & Aldosterone & 6.0 & $\mathrm{ng} / \mathrm{mL}$ & $3.6-24.0$ \\
\hline Cre & 0.19 & $\mathrm{mg} / \mathrm{dL}$ & PRA & 1.0 & $\mathrm{ng} / \mathrm{mL} / \mathrm{h}$ & $0.2-2.7$ \\
\hline $\mathrm{Na}$ & 121 & $\mathrm{mEq} / \mathrm{L}$ & ACTH & 8.9 & $\mathrm{pg} / \mathrm{mL}$ & $7.2-21.0$ \\
\hline K & 3.6 & $\mathrm{mEq} / \mathrm{L}$ & Cortisol & 5.5 & $\mu \mathrm{g} / \mathrm{dL}$ & $6.4-21.0$ \\
\hline $\mathrm{Cl}$ & 93 & $\mathrm{mEq} / \mathrm{L}$ & & & & \\
\hline TG & 198 & $\mathrm{mg} / \mathrm{dL}$ & & & & \\
\hline BG & 106 & $\mathrm{mg} / \mathrm{dL}$ & & & & \\
\hline Plasma Osm & 252 & $\mathrm{mOsm} / \mathrm{kg}$ & & & & \\
\hline Urinalysis & & & & & & \\
\hline Urine specific gravity & 1.024 & & & & & \\
\hline $\mathrm{Na}$ & 194 & $\mathrm{mEq} / \mathrm{L}$ & & & & \\
\hline Cre & 48 & $\mathrm{mEq} / \mathrm{L}$ & & & & \\
\hline Urine Osm & 708 & $\mathrm{mOsm} / \mathrm{kg}$ & & & & \\
\hline
\end{tabular}

TP, total protein; BUN, blood urea nitrogen; UA, uric acid; TG, triglycerides; BG, blood glucose; Osm, osmolality Cre, creatinine; $\mathrm{ADH}$, antidiuretic hormone; BNP, brain natriuretic peptide; PRA, plasma renin activity; $\mathrm{ACTH}$, adrenocorticotropic hormone.

The course of the first cycle of CARE chemotherapy is shown in Figure 1. A total volume of $1050 \mathrm{~mL}$ of fluids was administered on day 1 , and her serum sodium levels decreased to $115 \mathrm{mEq} / \mathrm{L}$ during CARE therapy on the morning of day 2, and she complained of neck pain and nausea. She was treated for symptomatic hyponatremia with $10 \mathrm{~mL}$ of $2.4 \% \mathrm{NaCl}$ per hour for $4 \mathrm{~h}$ by intravenous infusion, and her symptoms improved. Considering the possibility of worsening hyponatremia due to fluid infusion during CARE therapy, we decided to continue CARE therapy using tolvaptan $(0.20 \mathrm{mg} / \mathrm{kg} / \mathrm{dose})$ after 
obtaining the mother's consent. The in-out balance and the serum sodium level every $4 \mathrm{~h}$ after tolvaptan use are shown in Figure 2. After $4 \mathrm{~h}$ of tolvaptan administration, urine volume increased remarkably (maximum $15 \mathrm{~mL} / \mathrm{kg} / \mathrm{h}$ ). After $10 \mathrm{~h}$ of tolvaptan administration, the serum sodium level was normal $(138 \mathrm{mEq} / \mathrm{L})$. After $12 \mathrm{~h}$, the urine volume decreased prior to tolvaptan treatment. On the third day, tolvaptan $(0.20 \mathrm{mg} / \mathrm{kg} / \mathrm{dose})$ was again administered to prevent hyponatremia, and the serum sodium level remained normal during treatment (Figure 1). Subsequently, hyponatremia was also observed during the second and third courses of CARE therapy, and tolvaptan was used to appropriately manage the serum sodium levels.

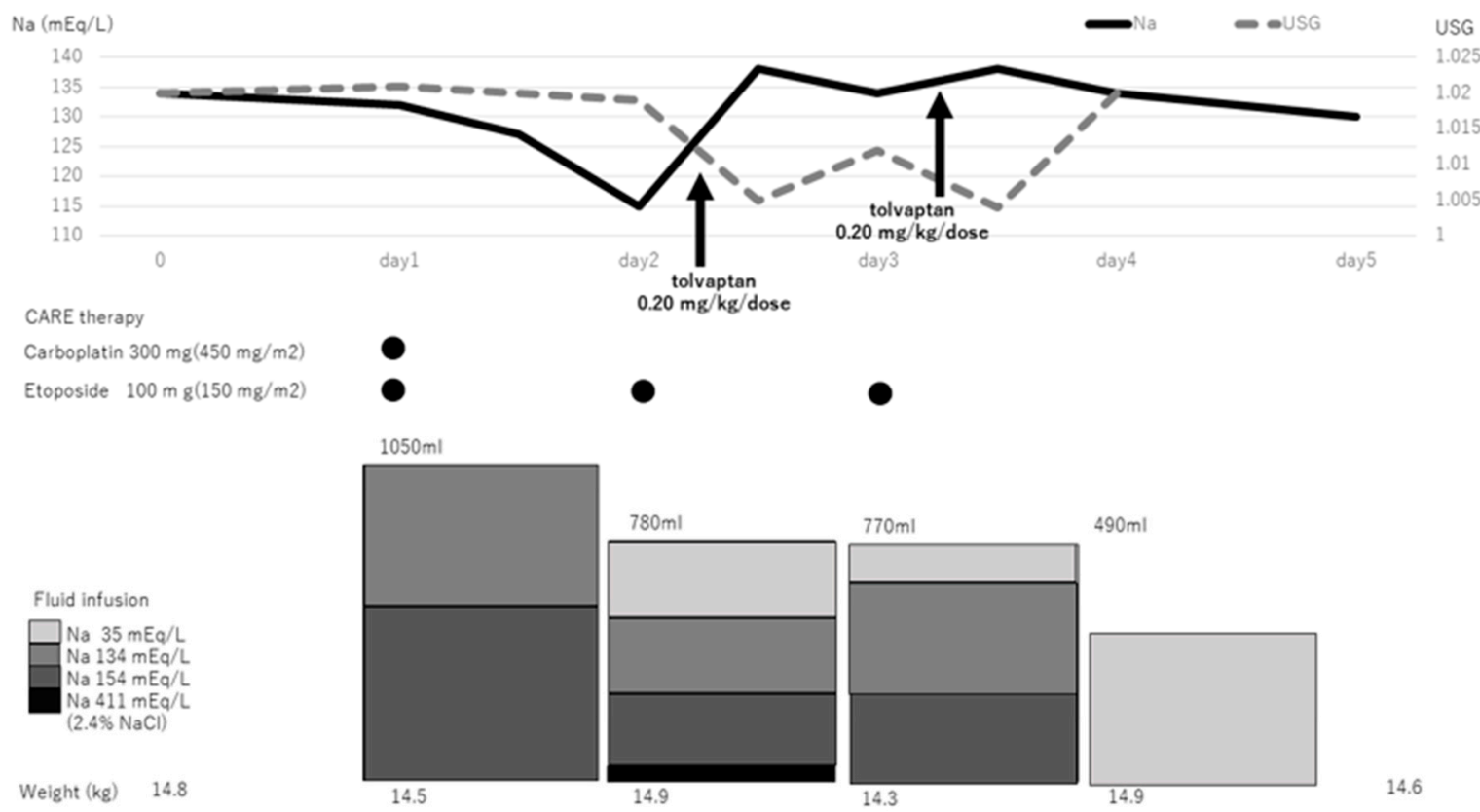

Figure 1. The first cycle of CARE chemotherapy. USG, urine specific gravity; CARE, carboplatin and etoposide combination chemotherapy.

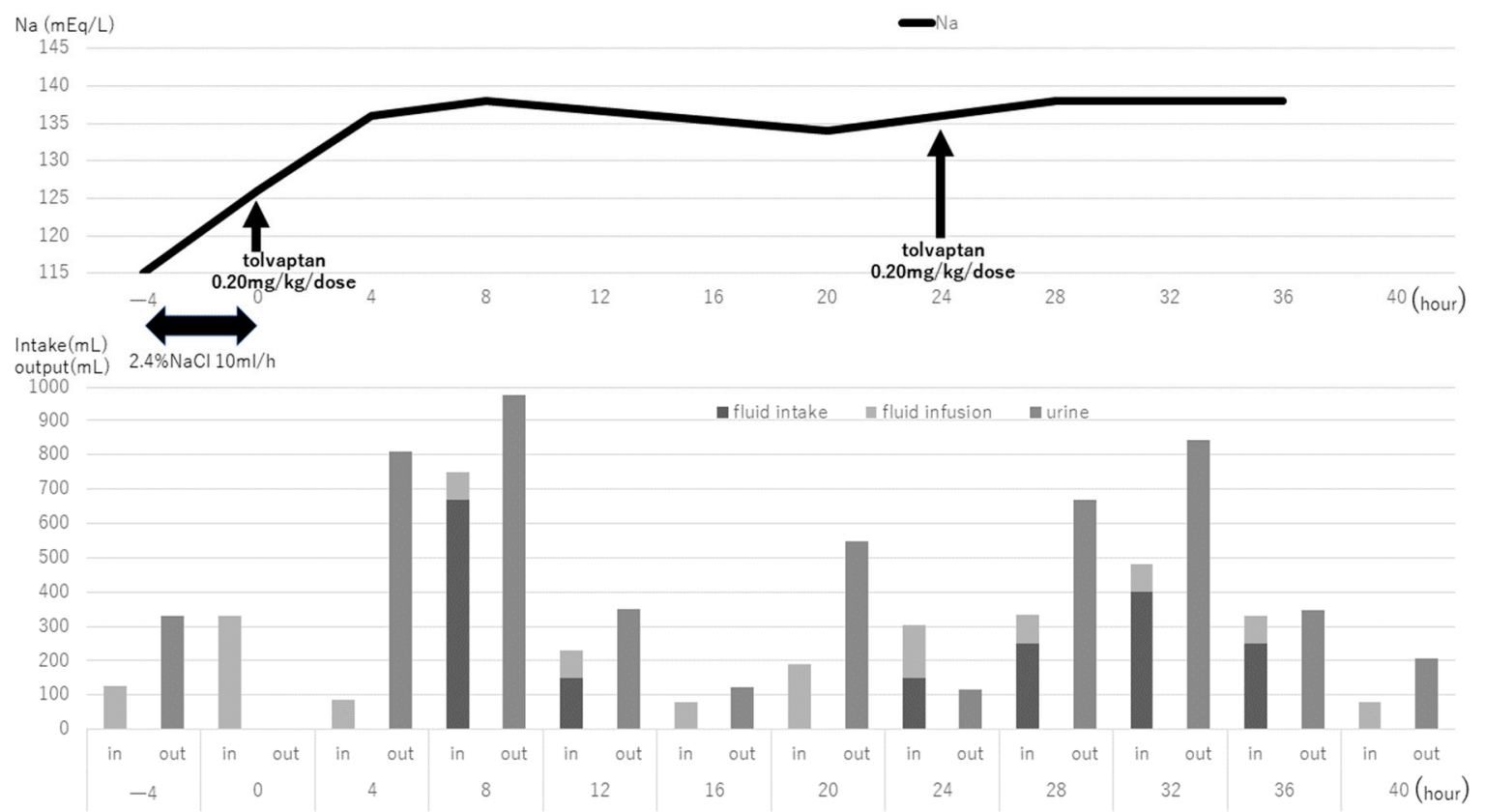

Figure 2. Changes in serum sodium levels and water intake and urine output after use of tolvaptan. The data in the bottom panel show the in-out balance data every $4 \mathrm{~h}$. 
This was a retrospective analysis of the clinical course of a patient examined and treated at the Niigata University Medical and Dental Hospital in Japan. The use of tolvaptan in this case was approved by the Clinical Ethics Review Committee of Niigata University Medical and Dental Hospital. Written informed consent was obtained from the mother.

The upper panel shows the changes in serum sodium levels and urine-specific gravity. The lower panel shows the sodium content of intravenous infusion. The color intensity of the square is proportional to the concentration of $\mathrm{Na}$.

\section{Discussion}

The cornerstone of SIADH treatment is water restriction, but fluid balance can be difficult to manage when fluids are needed, such as during chemotherapy. We report a pediatric case of hyponatremia due to hydration during chemotherapy in a four-year-old girl with a suprasellar germ cell tumor.

Reports of tolvaptan use for SIADH in children are limited [6-11]. The reported pediatric patients are summarized in Table 2. The age range was 0.2 to 17 years, and tolvaptan was used at various ages throughout childhood. Intracranial tumors were the most common cause of SIADH, but idiopathic and traumatic patients were also present. The initial dose of tolvaptan ranged from 0.05 to $0.8 \mathrm{mg} / \mathrm{kg} /$ dose. Referring to the initial dose of adult SIADH [5] and the report by Willemsen et al. [6] we have chosen an initial dose of $0.2 \mathrm{mg} / \mathrm{kg} /$ dose with good results.

Table 2. Reported pediatric patients that were administered tolvaptan for SIADH.

\begin{tabular}{|c|c|c|c|c|c|c|}
\hline Authors & $\begin{array}{c}\text { Age } \\
\text { (Years) }\end{array}$ & $\begin{array}{l}\text { Cause of } \\
\text { SIADH }\end{array}$ & $\begin{array}{l}\text { Initial Dose } \\
\text { of Tolvaptan } \\
\text { (mg/kg/dose) }\end{array}$ & Change in s-Na $(\mathrm{mEq} / \mathrm{L})$ * & $\begin{array}{l}\text { Maximum UV } \\
(\mathrm{mL} / \mathrm{kg} / \mathrm{h}) *\end{array}$ & References \\
\hline Koksoy, et al. & 16 & Idiopathic & 0.28 & 115 to 122 in $16 \mathrm{~h}$ & 9 & [10] \\
\hline Marx-Berger, et al. & 0.2 & Idiopathic & 0.8 & 138 to 153 in 2 days & No data & [9] \\
\hline Marx-Berger, et al. & 0.3 & Idiopathic & 0.6 & No data & No data & [9] \\
\hline Willemsen, et al. & 11 & $\begin{array}{c}\text { Intracranial B-cell } \\
\text { lymphoma }\end{array}$ & 0.14 & 119 to 130 in 2 days & 8 & [6] \\
\hline Tuli, et al. & 7 & $\begin{array}{l}\text { ROHHAD } \\
\text { syndrome }\end{array}$ & 0.06 & No data & No data & [7] \\
\hline Tuli, et al. & 4 & $\begin{array}{l}\text { A large sellar and } \\
\text { suprasellar tumor }\end{array}$ & 0.1 & No data & No data & [7] \\
\hline Tuli, et al. & 5 & Hypothalamic astrocytoma & 0.05 & No data & No data & [7] \\
\hline Gürbüz, et al. & 13 & Craniopharyngioma & 0.13 & 117 to 126 in $4 \mathrm{~h}$ & 8.1 & [8] \\
\hline Kraayvanger, et al. & 17 & Severe polytrauma & $15 \mathrm{mg} /$ day & 116 to 139 in $24 \mathrm{~h}$ & No data & [11] \\
\hline Hiroshima, et al. & 4 & Suprasellar germ cell tumor & 0.2 & 126 to $138 \mathrm{mEq} / \mathrm{L}$ in $10 \mathrm{~h}$ & 15 at $4 \mathrm{~h}$ & This study \\
\hline
\end{tabular}

* Changes after administration of tolvaptan; s-Na, serum sodium level; Osm, plasma osmolality; UV, urine volume; ROHHAD, rapid-onset obesity with hypothalamic dysregulation.

Management of sodium balance for SIADH during chemotherapy with massive infusion is difficult. Willemsen et al. reported the use of tolvaptan for hyponatremia associated with massive infusion during methotrexate therapy for intracranial B-cell lymphoma [6]. Tolvaptan treatment is useful in the management of serum sodium levels through a gradual increase in sodium levels, allowing for liberalizing fluid intake and hyperhydration [6]. In this study, we used tolvaptan prophylactically in combination with massive infusion and were able to keep the serum sodium level almost constant.

The onset and duration of action of tolvaptan in pediatric patients with SIADH are unknown. In the US Guidelines for hyponatremia, it is essential that the serum sodium concentration is measured frequently during the active phase of correction of hyponatremia at a minimum of every 6 to $8 \mathrm{~h}$ during the use of tolvaptan in adult patients with SIADH, particularly in patients with risk factors for osmotic demyelination [12]. In this study, the onset time of tolvaptan effect was 1 to $2 \mathrm{~h}$, and the maximum effect time was 4 to $8 \mathrm{~h}$, lasting approximately $12 \mathrm{~h}$, and serum sodium increased by $12 \mathrm{mEq} / \mathrm{L}$ in $10 \mathrm{~h}$. As data on the use of tolvaptan in children are scarce and safety cannot be guaranteed, closer monitoring is required during the use of tolvaptan in children than that in adults. 


\section{Conclusions}

The use of tolvaptan in pediatric patients with SIADH who require intravenous hydration during chemotherapy can be useful for the management of serum sodium balance.

Author Contributions: Conceptualization, S.H. and K.N.; writing—original draft preparation, H.N., S.S., Y.O., and K.N.; writing—review and editing. All authors have read and agreed to the published version of the manuscript.

Funding: This research received no external funding.

Institutional Review Board Statement: Ethical review and approval of Niigata University were waived for this study, due to a case report with no information identifying the patient.

Informed Consent Statement: Informed consent was obtained from the subject involved in the study.

Data Availability Statement: The data presented in this study are available upon request from the corresponding author. The data are not publicly available due to privacy restrictions.

Conflicts of Interest: The authors declare no conflict of interest.

\section{References}

1. Berl, T. Vasopressin antagonists. N. Engl. J. Med. 2015, 372, 2207-2216. [CrossRef] [PubMed]

2. Aditya, S.; Rattan, A. Vaptans: A new option in the management of hyponatremia. Int. J. Appl. Basic Med. Res. 2012,2 , 77-83. [CrossRef] [PubMed]

3. Cuesta, M.; Thompson, C.J. The syndrome of inappropriate antidiuresis (SIAD). Best. Pract. Res. Clin. Endocrinol. Metab. 2016, 30, 175-187. [CrossRef] [PubMed]

4. Rondon-Berrios, H. Urea for Chronic Hyponatremia. Blood Purif. 2020, 49, 212-218. [CrossRef] [PubMed]

5. Arima, H.; Goto, K.; Motozawa, T.; Mouri, M.; Watanabe, R.; Hirano, T.; Ishikawa, S.E. Open-label, multicenter, dose-titration study to determine the efficacy and safety of tolvaptan in Japanese patients with hyponatremia secondary to syndrome of inappropriate secretion of antidiuretic hormone. Endocr. J. 2021, 68, 17-29. [CrossRef] [PubMed]

6. Willemsen, R.H.; Delgado-Carballar, V.; Elleri, D.; Thankamony, A.; Burke, G.A.; Nicholson, J.C.; Dunger, D.B. Tolvaptan use during hyperhydration in paediatric intracranial lymphoma with SIADH. Endocrinol. Diabetes Metab. Case Rep. 2016, $2016,2016$. [CrossRef] [PubMed]

7. Tuli, G.; Tessaris, D.; Einaudi, S.; De Sanctis, L.; Matarazzo, P. Tolvaptan Treatment in Children with Chronic Hyponatremia due to Inappropriate Antidiuretic Hormone Secretion: A Report of Three Cases. J. Clin. Res. Pediatr. Endocrinol. 2017, 9, $288-292$. [CrossRef] [PubMed]

8. Gürbüz, F.; Taştan, M.; Turan, İ.; Yüksel, B. Efficiency of Single Dose of Tolvaptan Treatment During the Triphasic Episode After Surgery for Craniopharyngioma. J. Clin. Res. Pediatr. Endocrinol. 2019, 11, 202-206. [CrossRef] [PubMed]

9. Marx-Berger, D.; Milford, D.V.; Bandhakavi, M.; Van't Hoff, W.; Kleta, R.; Dattani, M.; Bockenhauer, D. Tolvaptan is successful in treating inappropriate antidiuretic hormone secretion in infants. Acta Paediatr. 2016, 105, 334-337. [CrossRef] [PubMed]

10. Koksoy, A.Y.; Kurtul, M.; Ozsahin, A.K.; Cayci, F.S.; Tayfun, M.; Bayrakci, U.S. Tolvaptan Use to Treat SIADH in a Child. J. Pediatr. Pharmacol. Ther. 2018, 23, 494-498. [CrossRef] [PubMed]

11. Kraayvanger, L.; Latza, J.; Vockelmann, C.; Berlit, P.; Weber, R. Tolvaptan treatment of severe stroke-like symptoms and bilateral subcortical diffusion restriction due to syndrome of inappropriate secretion of ADH after polytrauma. J. Neurol. 2014, 261, 1436-1438. [CrossRef] [PubMed]

12. Verbalis, J.G.; Goldsmith, S.R.; Greenberg, A.; Korzelius, C.; Schrier, R.W.; Sterns, R.H.; Thompson, C.J. Diagnosis, evaluation, and treatment of hyponatremia: Expert panel recommendations. Am. J. Med. 2013, 126, S1-S42. [CrossRef] [PubMed] 